Images in ...

\title{
Innovative bedside 'screening' test for myasthenia gravis
}

\author{
Syed Viqar Ahmed \\ Department of Acute Medicine, Stepping Hill Hospital, Poplar Grove, Stockport, UK
}

Correspondence to Syed Viqar Ahmed, syed.ahmed@stockport.nhs.uk

\section{DESCRIPTION}

A 76-year-old man presented with a 10-day history of drooping left eyelid followed by diplopia. Ophthalmology referral identified no abnormalities except vertical image separation successfully corrected with a prism. A normal cranial CT scan prompted referral for further evaluation. Relevant history included excessive tiredness and recent double vision. Past medical history was insignificant with no regular medications. Clinical examination confirmed left partial ptosis but detailed neurological examination, by the neurologist, could not elicit extra-ocular muscle or orbicularis oculi weakness. However, earlier, our innovative 'rapid eye blinking test' clearly demonstrated marked extra-ocular muscle weakness suggestive of myasthenia gravis (see video1). Strongly positive acetylcholine receptor antibodies confirmed the diagnosis and he was treated appropriately.

Video 1. Rapid Eye Blinking Test - a bedside 'screening' test for Myasthenia Gravis given before diagnosis, and after diagnosis and treatment (with steroids).bcr.08.2008.0724v1

Myasthenic patients classically develop progressive exercise-induced muscle weakness. During the course of illness, extra-ocular muscles are involved in over $90 \%$ of patients-ptosis being the predominant complaint. Diagnosis is confirmed by acetylcholine receptor antibodies (seropositive) detection. If negative, then muscle-specific kinase antibodies (Musk) detection, single-fibre EMG or tensilon (edrophonium) is used.
Few bedside screening tests ${ }^{1}$ for ptosis evaluation in suspected myasthenia gravis are mentioned but our 'rapid eye blinking test' is much simpler, non-invasive and easily performed test. It does not require special tools and is completed within $3 \mathrm{~min}$ in a cooperative patient of any age with no side-effects.

For the procedure, the patient is asked to blink their eyes repeatedly for $1 \mathrm{~min}$. Extra-ocular muscle fatigue causes the eyes to start closing, rendering the patient barely able to open them and visibly utilising forehead muscles. After a 2 min rest, where the patient is asked to close the eyes, on re-opening there will be visible improvement; thus, demonstrating weariness with exercise and quick recovery following rest. A healthy individual of similar age would not demonstrate this fatigue effect.

We recommend this as initial screening test for suspected myasthenia gravis. Independent studies may be needed to standardise and determine sensitivity/specificity of the test.

Acknowledgements Dr Rakesh Sajjan, Senior Clinical Fellow, Stepping Hill Hospital. Lesley Sutton, Advanced Nurse Practitioner, Stepping Hill Hospital.

Competing interests None.

Patient consent Obtained.

\section{REFERENCES}

1. Sethi KD, Rivner MH, Swift TR. Ice pack test for myasthenia gravis Neurology 1987;37:1383-5.

\footnotetext{
This pdf has been created automatically from the final edited text and images.

Copyright 2010 BMJ Publishing Group. All rights reserved. For permission to reuse any of this content visit http://group.bmi.com/group/rights-licensing/permissions.

BMJ Case Report Fellows may re-use this article for personal use and teaching without any further permission.

Please cite this article as follows (you will need to access the article online to obtain the date of publication).

Ahmed SV. Innovative bedside 'screening' test for myasthenia gravis. BMJ Case Reports 2010;10.1136/bcr.08.2008.0724, date of publication

Become a Fellow of BMJ Case Reports today and you can:

- Submit as many cases as you like

- Enjoy fast sympathetic peer review and rapid publication of accepted articles

- Access all the published articles

- Re-use any of the published material for personal use and teaching without further permission

For information on Institutional Fellowships contact consortiasales@bmjgroup.com

Visit casereports.bmj.com for more articles like this and to become a Fellow
} 